\title{
Pembelajaran Alternatif Berbasis Proyek Kreatif Rumah pada Masa Pandemi Covid-19
}

\author{
Ririen Wardiani \\ STKIP PGRI Ponorogo \\ wardianiririen@gmail.com \\ Rifa Suci Wulandari
STKIP PGRI Ponorogo
rifaw1981@gmail.com \\ Cutiana Windri Astuti \\ STKIP PGRI Ponorogo \\ cutiana84@gmail.com \\ Lusy Novitasari \\ STKIP PGRI Ponorogo \\ lucydheny77@gmail.com
}

\begin{abstract}
This research aims to describe alternative home based learning activities, home used as learning source. That learning alternative is derived from the concept of Multiple Intelligences development, Home as Finnish learning setting education and emergency curriculum proposed by Kemendikbud. The method used is library analysis. The discussion about this learning alternative focuses on kinesthetic intelligence so that it can be done easily by parents. The form of learning alternative is creative project involves My creation, My sport, a Dancer, Traditional Games, Outbound, Fun Cooking, Gardening. That creative project is valued academic activities based on Basic Competence stated in curriculum. Teaching and learning process in Elementary level mainly focuses on thematic integrative learning. The proposed learning alternative can facilitate the students to reach the essential basic competence recomended by the school. In this case, learning alternative is correlated with literacy competence, numeric, character education, and life skill.
\end{abstract}

Keywords : learning, alternatives, home creative projects

\section{Pendahuluan}

Pandemi covid-19 ini mengubah hampir seluruh tatanan kehidupan. Terjadinya pergeseran paradigma ini membutuhkan daya adaptasi yang kuat. Sampai dengan saat ini jumlah yang terpapar mencapai 184.268 kasus (Gugus Tugas Percepatan Penanganan COVID-19, 2020). Melihat ini kita harus mampu beradaptasi dengan tatanan hidup baru. Tam dan El Azar (2020) menyatakan pandemi virus corona menyebabkan tiga perubahan mendasar di dalam pendidikan global. Pertama, mengubah cara jutaan orang di didik. Pemberlakuan bekerja dari rumah (work from home) dan belajar dari rumah (learning from home) ini mengubah tatanan yang telah terbentuk dengan pembelajaran tatap muka. Kedua, solusi baru untuk pendidikan yang dapat membawa inovasi sangat dibutuhkan. Pemberlakuan pembelajaran di rumah membuat semua komponen bergerak untuk sadar teknologi. Ketiga, adanya kesenjangan digital menyebabkan pergeseran baru dalam pendekatan pendidikan 
dan dapat memperluas kesenjangan. mengedepankan prosedur aktivitas dengan media yang terdapat di rumah.

Di Indonesia pembelajaran daring atau pembelajaran jarak jauh diatur melalui Surat Edaran Kemendikbud No 4 Tahun 2020 mengenai Pelaksanaan Pendidikan dalam Masa Darurat Coronavirus Disease (Covid-19). Ada tiga poin kebijakan terkait pembelajaran daring, pertama, pembelajaran daring/jarak jauh untuk memberi pengalaman belajar yang bermakna, tanpa terbebani tuntutan menuntaskan seluruh capaian kurikulum untuk kenaikan kelas maupun kelulusan. Kedua, pembelajaran dapat difokuskan pada pendidikan kecakapan hidup, antara lain mengenai pandemi Covid-19. Ketiga, aktivitas dan tugas pembelajaran dapat bervariasi antar siswa, sesuai minat dan kondisi masing-masing, termasuk mempertimbangkan kesenjangan akses/fasilitas belajar di rumah, bahwa covid 19 ini mengakibatkan kesenjangan akses teknologi.

Merujuk dari UNDP (2020:14-15) dijelaskan bahwa akses teknologi yang tidak merata memiliki efek yang cukup besar pada kemampuan masyarakat dalam menghadapi COVID-19. Ketidaksetaraan dalam sarana dan dukungan yang ada di rumah menyebabkan ketidaksetaraan pengalaman dalam pembelajaran online. Gangguan dalam pendidikan karena COVID-19 belum pernah terjadi sebelumnya. Sekolah telah ditutup secara nasional di setidaknya 147 negara, yang memengaruhi lebih dari 1,4 miliar anak-anak dan remaja, sekitar 86 persen dari populasi siswa dunia. Ini adalah perkembangan yang mengejutkan bagi anak-anak yang bersekolah, dengan konsekuensi jangka panjang untuk potensi mereka.

Komisi Perlindungan Anak Indonesia (2020) melakukan survei pembelajaran jarak jauh (PJJ) yang berlangsung selama empat minggu. Survei dilakukan pada 13 April20 April 2020 dengan total responden 1.700 gabungan siswa dari jenjang TK sampai SMA/sederajat dan tersebar di 20 provinsi dan 54 kabupaten/kota. Dari 1.700 responden, sebanyak $77,8 \%$ siswa kesulitan karena tugas yang menumpuk antar guru. Terlebih, waktu pengumpulan tugas yang terbilang pendek. Sedangkan $37,1 \%$ responden mengeluhkan waktu pengerjaan tugas yang sempit sehingga membuat siswa kurang istirahat dan kelelahan. Kesulitan selanjutnya dalam pembelajaran jarak jauh dengan sistem daring adalah terkait masalah kuota internet. Sebanyak $42,2 \%$ mengaku tidak memiliki kuota yang memadai. Kesulitan siswa lainnya ialah tidak memiliki peralatan yang dibutuhkan, seperti perangkat laptop atau komputer. Hal ini ditemukan sekitar 15,6\% siswa dari total keseluruhan responden.

Berdasarkan penelitian yang dilakukan oleh Zhang (2020:8-9) di Cina diperoleh hasil bahwa faktor-faktor yang memengaruhi kualitas belajar-mengajar jarak jauh darurat dari sudut pandang orang tua menunjukkan tantangan untuk kualitas pengajaran jarak jauh darurat, yaitu: 1) pengajaran jarak jauh tidak ada bandingannya dengan pengajaran tatap muka; 2) teknologi glitchy untuk kelas online dan koneksi internet yang tidak stabil sangat memengaruhi kualitas belajarmengajar jarak jauh. Misalnya, orang tua mengeluh tentang kelas langsung dan mikrofon offline. Itu sangat memengaruhi efisiensi belajar mengajar; 3) guru tidak dapat memantau dan menilai hasil belajar siswa secara formatif dan efektif karena waktu instruksi terbatas dalam mode jarak jauh. Bagi guru, faktor utama yang mempengaruhi kualitas pengajaran jarak jauh terdiri dari: 1) manajemen kelas yang terpencil; 2) kompetensi mengajar online yang tidak memadai 3) tidak efektif cara melakukan penilaian seluruh kelas atau penilaian formatif; 4) beban kerja yang berat dan berlapis-lapis; 5) sulit memenuhi semua kebutuhan belajar siswa.

Sebagian besar pemerintah di seluruh dunia telah menutup sementara lembaga pendidikan dalam upaya penyebaran pandemi COVID-19. Penutupan nasional ini berdampak pada lebih dari $60 \%$ populasi siswa dunia. Beberapa negara lain telah 
menerapkan penutupan lokal yang berdampak pada jutaan pelajar tambahan. UNESCO mendukung negara-negara dalam upaya mereka untuk mengurangi dampak langsung dari penutupan sekolah, khususnya bagi masyarakat yang lebih rentan dan kurang beruntung, dan untuk memfasilitasi kesinambungan pendidikan bagi semua melalui pembelajaran jarak jauh (UNESCO, 2020).

Mencermati kondisi di atas, beberapa hal yang perlu segera disosialisasikan adalah bagaimana mengemas pembelajaran oleh orang tua dengan setting rumah atau bagaimana mengemas pembelajaran dengan memanfaatkan rumah sebagai sumber belajar? Berikut ini akan dibahas tentang pembelajaran alternatif berbasis rumah pada masa pandemi Covid 19. Beberapa hal yang mendasari penawaran pembelajaran berbasis rumah adalah konsep pembelajaran yang mengedepankan bahwa setiap anak cerdas dengan Multiple Intelligences, pembelajaran di Finlandia yang mengemas pembelajarannya berbasis rumah, dan anjuran Menteri Pendidikan dan Kebudayaan yang menyarankan dengan membuat Kurikulum Darurat. Konsep Kurikulum Darurat adalah kurikulum yang memilih KD esensial untuk dilaksanakan oleh anak dan dapat dengan mudah diterapkan di rumah bersama orang tua.

Untuk mengantisipasi konsekuensi negatif dan isu dari pembelajaran jarak jauh, pemerintah mengimplementasikan dua kebijakan baru di masa Pandemi COVID-19 ini. Yaitu, perluasan pembelajaran tatap muka untuk zona kuning dan Kurikulum darurat (dalam kondisi khusus). Pelaksanaan pembelajaran tatap muka diperbolehkan untuk semua jenjang yang berada zona hijau dan zona kuning. Sekolah diberi fleksibilitas untuk memilih kurikulum yang sesuai dengan kebutuhan pembelajaran siswa. Modul pembelajaran dan asesmen dibuat untuk mendukung pelaksanaan kurikulum darurat (dalam kondisi khusus) (Kemendikbud, 2020:5).

Kurikulum darurat merupakan penyederhanaan kompetensi dasar yang mengacu pada kurikulum 2013. Penyederhanaan kompetensi dasar untuk setiap mata pelajaran sehingga berfokus pada kompetensi esensial dan kompetensi prasyarat untuk kelanjutan pembelajaran di tingkat selanjutnya. Pelaksanaan kurikulum berlaku sampai akhir tahun ajaran (tetap berlaku walaupun kondisi khusus sudah berakhir) (Kemendikbud,2020:8).

Kurikulum darurat diharapkan dapat membantu mengurangi kendala yang dihadapi guru, orang tua, dan anak selama masa pandemi. Modul pembelajaran mencakup uraian pembelajaran berbasis aktivitas untuk guru, orang tua, dan siswa. Modul berorientasi pada kompetensi literasi, numerasi, pendidikan karakter, dan kecakapan hidup. Kompetensi dasar mencakup berbagai mata pelajaran. Modul diharapkan akan mempermudah guru untuk memfasilitasi dan memantau pembelajaran siswa dirumah dan membantu orang tua dalam mendapatkan tips dan strategi dalam mendampingi anak belajar dari rumah (Kemendikbud, 2020:19). Contoh aktivitas numerasi yang dapat dilakukan anak-anak di rumah adalah ketika merancang resep masakan bersama ibu. Dalam aktivitas tersebut anak-anak belajar tentang takaran bahan dan bumbu-bumbu yang dibutuhkan. Anak- anak belajar secara kontekstual untuk memahami konsep numerasi dan critical thinking serta membangun karakter karena mereka harus menjaga hubungan dengan aktivitas yang dia lakukan bersama ibunya. Membangun hubungan yang erat dalam sebuah aktivitas. Kurikulum darurat ini yang menjadi acuan agar Pembelajaran Jarak Jauh (PJJ) ini bisa lebih efektif.

Gardner (1993: $\mathrm{x}$ ) mengatakan bahwa "Intelligence is the ability to solve problems, or to create products, that are valued within one or more cultural". Menurutnya kecerdasan seseorang tidak diukur dari hasil tes psikologi standar, namun dapat dilihat dari kebiasaan seseorang menyelesaikan masalahnya sendiri dan kebiasaan 
seseorang menciptakan produk-produk baru yang mempunyai nilai budaya (creativity). Multiple intelligences merupakan teori kecerdasan yang dikemukakan oleh Howard Gardner, seorang psikolog dari Harvard University, bahwa setiap anak punya kecenderungan kecerdasan dari sembilan kecerdasan, yaitu cerdas bahasa (linguistik), cerdas matematis-logis (kognitif), cerdas gambar dan ruang (visualspasial), cerdas musik, cerdas gerak (kinestetis), cerdas bergaul (interpersonal), cerdas diri (intrapersonal), cerdas alam, dan cerdas eksistensial (Chatib,2012:87-88).

Multiple intelligences memiliki karakteristik konsep sebagai berikut. Semua inteligensi itu berbeda-beda, tetapi semuanya sederajat. Dalam pengertian ini, tidak ada inteligensi yang lebih baik atau lebih penting dari inteligensi yang lain (Gardner, 1993; Hine; 2003; Armstrong, 1993; 1996). Semua kecerdasan dimiliki manusia dalam kadar yang tidak persis sama. Semua kecerdasan dapat dieksplorasi, ditumbuhkan, dan dikembangkan secara optimal. Terdapat banyak indikator kecerdasan dalam tiap-tiap kecerdasan. Dengan latihan, seseorang dapat membangun kekuatan kecerdasan yang dimiliki dan menipiskan kelemahankelemahan. Semua kecerdasan yang berbeda-beda tersebut bekerjasama untuk mewujudkan aktivitas yang diperbuat manusia. Satu kegiatan mungkin memerlukan lebih dari satu kecerdasan, dan satu kecerdasan dapat digunakan dalam berbagai bidang (Gardner, 1993: 37-38).

Thomas Armstrong mempelajari dan mengaplikasikan teori Multiple intelligences ke dalam dunia kelas sehingga dia berhasil menjelaskan hal-hal penting Multiple intelligences anak. Hal penting tersebut adalah, semua kecerdasan itu sederajat meskipun masing-masing punya kriteria yang berbeda, kecerdasan tersebut dinamis, setiap anak dapat memiliki beberapa kecerdasan sekaligus, setiap kecerdasan punya banyak indikator, indikator kecerdasan yang berbeda-beda saling bekerja sama hampir di setiap aktivitas anak kita (Armstrong, 2004: 11-12).

Kondisi sekarang yang mengharuskan anak di rumah saja (stay at home) memberikan kesempatan yang luas bagi setiap anak untuk mendapatkan pendidikan langsung dari keluarga. Hal ini menjadi kesempatan yang baik bagi orang tua untuk membentuk waktu yang berkualitas (quality time) bersama anakanaknya. Menjadi momentum bagi orang tua untuk kembali "mengenal" anakanaknya. Menjelajahi kemampuan anaknya. Bahwa anak-anak memiliki kemampuan yang seluas samudra. Setiap anak mempunyai harta karun dalam dirinya, setiap anak mempunyai potensi dan multiple intelligences. Betapa banyak orang tua yang terjebak sehingga menilai kemampuan anak dari sudut pandang sempit, yaitu hanya pada kemampuan kognitif mereka, sedangkan kemampuan afektif dan psikomotorik yang luas malah diabaikan.

Tujuan utama pendidikan adalah untuk mewujudkan high-level education for all. Keluarga adalah pendidikan pertama dan utama. Kenyataan saat ini mengembalikan pembelajaran itu di keluarga. Peran orang tua menjadi sangat esensial. Merujuk pendidikan ideal pendidikan keluarga yang ada di Finlandia. Pendidikan di Finlandia jarang mengganti kurikulum pendidikannya. Perencanaan kurikulum adalah tanggung jawab guru, sekolah dan pemerintah kota, bukan pemerintah pusat. Peserta didik di Finlandia memiliki jam belajar yang relatif singkat di sekolah. Mereka tidak dibebani dengan banyak pekerjaan rumah, ujian terstandar bertaruhan tinggi dan tidak ada sistem ranking. Pembiayaan pendidikan di Finlandia dari jenjang sekolah dasar hingga pendidikan tinggi dan pendidikan orang dewasa, hampir sepenuhnya dengan sumber publik (Bautty, 2016:82). Pendidikan sejatinya adalah pendidikan dalam keluarga. Di rumah anak bisa belajar apa saja. Setting rumah berpotensi untuk pembelajaran anak di rumah. 


\section{Metode}

Metode yang digunakan adalah metode penelitian kepustakaan. Penelitian kepustakaan (library research) merupakan penelitian yang dilakukan dengan cara mengumpulkan karya tulis ilmiah sebagai objek penelitian atau mengumpulkan data yang bersifat kepustakaan sehingga tidak dibutuhkan lagi penelitian langsung ke lapangan. Selanjutnya data tersebut digunakan untuk menyelesaikan suatu permasalahan yang dikaji secara mendalam terhadap bahan-bahan pustaka yang relevan. Lebih lanjut (Gary \& Arsenault, 1998) menyatakan bahwa kajian pustaka ditujukan untuk meringkas, menganalisis, dan menafsirkan konsep dan teori yang berkaitan dengan sebuah proyek penelitian. Penelitian ini difokuskan pada pembelajaran alternatif dengan rumah sebagai sumber belajar dengan melakukan proyek-proyek kretaif yang bisa dilaksanakan di rumah khusus untuk pembelajaran berbasis kecerdasan kinestetik. Penawaran proyek kreatif sebagai pembelajaran alternatif ini akan dikaji dari rekomendasi Menteri Pendidikan tentang kurikulum darurat yang mengutamakan Kompetensi Dasar (KD) esensial dan kompetensi tambahan. Keutamaanya mendukung kemampuan literasi, kemampuan numerik, pendidikan karakter, dan life skill.

\section{Hasil}

Pembelajaran Alternatif di Rumah Berdasarkan Kecerdasan Kinestetik. Terdapat beberapa proyek kreatif yang dirumuskan dan ditawarkan serta dapat dilakukan oleh orang tua di rumah dengan mengacu pada kecerdasan kinestetik atau kemampuan seseorang dengan menggunakan seluruh kekuatan fisik atau tubuh untuk mengekspresikan ide, perasaan, dan keterampilan.

Proyek Kreatif Karyaku. Karyaku adalah kegiatan yang dapat dilakukan anak dengan cara membiasakan membuat kerajinan tangan berbagai karya. Aktivitas ini dapat menjadi cara yang bagus untuk menghindari anak dari kebosanan di rumah. Orang tua dapat memanfaatkan bahan-bahan yang ada di rumah, misalnya membuat mahkota dari kertas, atau kerajinan lainnya. Beberapa ide lainnya, orang tua dapat mengajak anak membuat kartu ucapan untuk anggota keluarga yang dilukis atau diberi hiasan sticker dan manik-manik. Penggunaan bahan-bahan bekas yang ada di rumah merupakan alternatif strategi pembelajaran yang dapat dipilih orang tua. Pemanfaatan kertas origami dapat melatih fokus dan konsentrasi anak, terjadi peningkatan pada kecakapan visual dan spasial, melatih mengikuti instruksi yang runut, serta pengenalan berbagai konsep matematika, seperti ukuran, pola, dan geometri (Respitawulan et al., 2014). Proyek Kreatif Karyaku ini bernilai akademik untuk pencapai KD yang mengarah pada kemampuan bahasa dengan menjelaskan langkah-langkah pembuatan karya tersebut baik secara lisan maupun tertulis, baik menggunakan Bahasa Indonesia, Bahasa Inggris, maupun Bahasa Daerah. Proyek Kreatif Karyaku bernilai pula pemanfaatan barang bekas merupakan usaha mengurangi polusi dan menciptakan go green. KD yang disesuaikan dengan ini siswa dapat mempraktikan menjaga lingkungan sekitar. Anak bisa diajak untuk menghitung biaya produksi dan prediksi untuk dijual.

Proyek Kreatif My Sport, anak difokuskan untuk menyenangi dan melakukan rutin olahraga yang disenangi anak. Pemanfaatan olahraga ini dapat menjadi alternatif pembelajaran bagi anak. Seperti pengenalan konsep jarak dan waktu dapat dilakukan dengan menghitung langkah ketika masuk kedalam kamar, hal sederhana tersebut menjadikan matematika merupakan bagian dari aktivitas keseharian anak di rumah (Fitria, 2013). Menurut penelitian Purwantyo \& Tomoliyus (2017) permainan bola dapat meningkatkan kemampuan sikap (ketertiban dan percaya diri), keterampilan (melempar), dan pengetahuan (penguasaan pengetahuan 
permainan dan ketepatan menghitung jumlah bola). Mata pelajaran PKn masuk aspek sikap (ketertiban dan percaya diri), Mata Pelajaran Pendidikan Jasmani Olah raga dan Kesehatan masuk dalam aspek keterampilan (gerak dasar melempar), mata Pelajaran Matematika dan Bahasa Indonesia masuk aspek pengetahuan (penguasaan pengetahuan permainan dan menghitung jumlah bola).

Proyek Kreatif Sang Penari, bersama-sama berolahraga ditemani musik dan melakukan tarian unik. Dengan kegiatan menari ini juga dapat digunakan untuk mengenalkan konsep bentuk dengan gerak. Anak akan lebih mudah mengenali huruf dengan menggunakan gerakan, begitu juga dengan konsep panjang pendek yang dipraktikan dengan lengan. Anak dapat mengenal konsep angka dalam kegiatan menari, karena dalam menari akan ada hitungan-hitungan. Hal ini sejalan dengan pendapat Maritaria (2019: 3030) bahwasanya ia menemukan ilmu Matematika sebagai dasar untuk membuat gerak tari seperti bilangan, bangun datar, garis dan sudut. Bilangan digunakan untuk menentukan tempo dan hitungan gerak pada tarian yang pada umumnya menggunakan bilangan 1 sampai 8. Pola lantai pada tarian akan membentuk sebuah garis dan bangun datar. Sudut digunakan untuk menentukan seberapa posisi tangan dan kaki penari.

Proyek Kreatif Permainan Rakyat, bermain bersama dengan permainan rakyat (permainan tradisional seperti engkleng, lompat tali, bermain layang-layang dan lain-lain). Menerbangkan layangan mensyaratkan anak-anak berada di alam terbuka yang lapang. Layang-layang bisa terbang tinggi, ia harus berlari untuk menerbangkannya. Berlari akan meningkatkan detak jantungnya, dan merupakan salah satu latihan yang bagus untuk fisik anak. Aktifitas menerbangkan layangan dapat mengembangkan kreativitas anak, baik dalam pembuatan layangan maupun proses penerbangannya dan menyesuaikannya dengan perubahan angin. Hal ini juga bisa jadi cara untuk anak belajar memahami dinamika angin. Araujo, et.al. (2013), menyatakan bahwa permainan tradisional seperti pathilan, dakon, nekeran, kubuk manuk, pasaran, bundaran, dan sebagainya dapat digunakan untuk mempelajari konsep berhitung pada anak. Selain itu, permainan tradisional engkleng dapat dimanfaatkan untuk mempelajari konsep luas bangun datar persegi, persegi panjang, dan trapesium (Damayanti, 2016). Hal ini senada dengan hasil penelitian Rahayu (2016) bahwa permainan edukasi berbasis keunggulan lokal dapat dijadikan sebagai media pembelajaran Matematika dengan mengaitkan proses pembelajaran dengan budaya lokal siswa. Dengan permainan tradisional, diharapkan siswa dapat mengoptimalkan hasil belajar Matematika sekaligus mempelajari budaya khususnya yang berada di daerahnya. Dengan mengenal budaya yang ada di daerahnya, siswa dapat ikut menjaga dan melestarikan budaya tersebut. Permainan pasaran, siswa memperagakan proses jual beli seperti pada kondisi pasar yang sebenarnya. Dengan pengalaman langsung seperti itu, siswa akan lebih memahami konsep aritmatika sosial. Sebagai contoh permainan ular naga dapat melatih keterampilan berbicara bagi kelas bawah. Anak bisa mendeskripsikan tumbuhan atau binatang di sekitar sesuai ciri-cirinya dengan menggunakan kalimat yang mudah dipahami orang lain (Praheto, 2018: 402).

Proyek Kreatif Outbound, melakukan permainan outbound. Melalui kegiatan outbound ini secara tidak langsung pendidikan karakter masuk ke dalam permainan outbound. Melalui perencanaan pembelajaran, penerapan pembelajaran lewat penyampaian aturan permainan, bentuk permainan, dan refleksi setelah permainan. Karakter yang dapat dikuatkan dalam pembelajaran outbound ini antara lain: karakter percaya diri, religius, jujur, ketelitian, kedisiplinan, konsentrasi, kerjasama, pantang menyerah, semangat untuk berbagi, simpati, empati, kerjasama, disiplin, tanggung jawab, peduli terhadap teman, jiwa kepemimpinan (leadership), peduli lingkungan. Dalam kegiatan outbound pembelajaran yang berkaitan dengan materi sains dapat diserap dengan mudah karena secara langsung berinteraksi 
dengan alam. Outbound sains yang menekankan pembelajaran secara langsung di lapangan membuat anak dapat belajar dan berinteraksi secara langsung dengan sekitar atau lingkungan. Kandungan alam yang banyak dipelajari ini sangat bersentuhan secara langsung dengan pembelajaran PAI yang mengkaitkan penciptaan femonema alam terhadap sang pencipta.

Proyek Kreatif Fun Cooking, kegiatan memasak bersama di dapur mempunyai nilai postif. Bersama anak kita bisa mengenalkan banyak kosa kata dengan cara melebel semua benda yang ada di dapur, melebel nama bahan masakan yang akan dimasak. Pengembangan bahasa secara lisan dan tulis, serta melebel benda dengan menggunakan Bahasa Indonesia, Bahasa Inggris, maupun Bahasa Daerah. Proyek Kreatif fun cooking ini bisa dijadikan praktik bahwa semua benda itu bisa untuk pencapaian KD mampu membedakan perubahan bentuk benda dengan menyusut, memuai, mencair, dan lain - lain. Kegiatan dapat dilakukan bersama dengan anggota keluarga. Ini akan memupuk rasa cinta, menghargai, dan kerja sama sesuai harapan pendidikan Agama. Proyek Kreatif fun cooking dapat pula untuk kegiatan belajar membaca. Anak-anak dapat belajar membaca melalui tulisan bahan-bahan yang diperlukan saat memasak. Anak juga dapat belajar matematika. Kegiatan fun cooking mengandung kegiatan yang matematis. Seperti mengenal bentuk benda, menimbang, berhitung, menambahkan mengurangi takaran, dan sebagainya. Hal tersebut memberikan kontribusi positif terhadap peningkatan kemampuan matematika anak. Hal ini sejalan dengan penelitian yang dilakukan oleh (Mirawati et al., 2018), bermain masak-masakan bersama (fun cooking) merupakan salah satu strategi menghilangkan kejenuhan dan kebosanan yang dapat menjadi alternatif orang tua membelajarkan konsep matematika yang mengasyikkan dan menyenangkan bersama anak. Proses matematis terjadi melalui kegiatan fun cooking tersebut seperti menimbang, berhitung, menambahkan mengurangi takaran, dan membentuk pola kue, sehingga memberi kontribusi positif terhadap peningkatan kemampuan matematika anak sejak dini. Hal di atas sejalan dengan cara bermain matematika yang menyenangkan dengan anak di rumah yang disampaikan oleh (Kemdikbud, 2020), bahwa dalam mengenalkan konsep matematika kepada anak dapat dilaksanakan kapan saja dan dimana saja seperti di rumah, di sekolah, di jalan dan di sekitar lingkungan tempat tinggal. Kegiatan bermain matematika yang dilakukan di rumah bisa memanfaatkan ruang tamu seperti mencari benda yang bentuknya segi empat di ruang tamu, dimanakah aku (mengenalkan konsep posisi), menghitung jumlah kursi dan meja, halaman dengan menghitung panjang dan lebar halaman, menghitung tanaman mengurutkan ketinggian tanaman dan berapa plat motor ayah?, kegiatan main matematika di ruang makan seperti, kamar tidur seperti membantu ibu melipat baju, menyusun bantal untuk mengetahui tinggi rendah, memasangkan sarung bantal, dapur seperti pasangan panci dan tutup gelas, membantu ibu mengelompokkan bumbu dapur, menyusun pola sederhana (sendok garpu gelas, sendok garpu gelas).

Proyek Kreatif Berkebun, kegiatan yang bersifat kinestetik yang melibat alam. Anak-anak sering kali melihat gambar visual. Hal ini sering kali tidak menarik. Lebih menarik, jika anak bisa dilibatkan secara aktif dengan media alam yang sebenarnya. Ajak anak ke kebun rumah dan biarkan ia menyentuh dan melihat langsung jenis tumbuhan yang ingin dikenalkan pada anak. Orang tua juga dapat memanfaatkan limbah dapur seperti tomat busuk bisa diambil biji lalu ditanam. Penelitian Lestariningrum (2015), salah satu strategi yang bisa di manfaatkan oleh orang tua agar anak mudah memahami dan belajar konsep matematika yang tidak memerlukan sumber belajar yang mahal yaitu dengan menggunakan benda-benda di sekitar anak adalah dengan memanfaatkan biji-bijian. Kegiatan berkebun ini juga mengajari anak untuk mengenal sains. Charlesworth \& Lind (2010); Asiah (2012); Nugraha (2008) memapaparkan bahwa kegiatan berkebun mengandung kompetensi Dasar yakni keterampilan mengamati yaitu keterampilan anak dalam melibatkan 
semua alat indra untuk menyatakan sifat yang dimiliki oleh suatu benda atau objek. Kemampuan membandingkan yaitu keterampilan anak melihat persamaan dan perbedaan dari objek atau benda yang diamati sehingga memperoleh perbandingan. Keterampilan mengklasifikasikan yaitu kemampuan anak dalam mengelompokkan benda atau objek berdasarkan sifat yang diamati dan dibandingkan. Keterampilan mengukur yaitu kemampuan anak mengukur atau menilai objek atau benda. Keterampilan menduga yaitu kemampuan anak memprediksi atau memperkirakan suatu kejadian. Keterampilan mengomunikasikan yaitu kemampuan anak menyampaikan informasi yang diperoleh (dalam Nugraha. 2017:9). Pendekatan saintifik menjadi lebih konkret.

\section{Simpulan}

Pandemi Covid-19 ini mampu menciptakan transformasi pendidikan. Ini membutuhkan kesadaran di setiap lini pendidikan. Pergeseran paradigma ini menjadi sesuatu yang tidak bisa dielakkan. Pola pembelajaran konvensional berbasis tatap muka di sekolah bergeser menjadi pembelajaran jarak jauh yang sangat mengandalkan teknologi. Pembelajaran luring ke daring. Pembelajaran daring dengan berbagai keterbatasannya membuat sekolah dan orang tua perlu dibekali pembelajaran alternatif. Pembelajaran alternatif yang berbasis rumah ini dengan melakukan proyek kreatif berbasis Multiple Intelligences. Pembelajaran alternatif tersebut diantaranya adalah proyek kreatif berupa Karyaku, My Sport, Sang Penari, Permainan Rakyat, Outbound, Fun Cooking, Berkebun. Proyek kreatif tersebut merupakan aktivitas yang bernilai dan bermuatan akademis yang disesuaikan dengan Kompetensi Dasar (KD) yang harus dicapai oleh anak. Pembelajaran di SD sangat mengutamakan pembelajaran tematis integratif, sehingga melalui proyek kreatif tersebut dapat tercapai beberapa KD esensial yang direkomendasikan sekolah dan dapat dilakukan oleh orang tua di rumah. Fokus pada kemampuan literasi, numerik, pendidikan karakter, dan life skill.

\section{Saran}

Berdasarkan hasil kajian ini disarankan untuk menindaklanjuti kajian dengan berfokus pada kecerdasan yang lain bisa dilakukan untuk lebih detail diantaranya kecerdasan visual spasial, linguistik, intrapersonal, interpersonal, naturalis, musikal, logis matematis dapat dilanjutkan oleh peneliti lain.

\section{Referensi}

Anderson, G. \& Nancy, A. (1998). Fundamentals of Educational Research, 2nd Edition. Philadelphia: The Falmer Press.

Araujo, et. al. (2013). Peningkatan Kemampuan Belajar Hitung Pada Anak Melalui Ragam Permainan Kreatif. Prosiding Elektronik PIMNAS. (online). Diakses pada 12 Agustus 2020. https://media.neliti.com/media/publications/169955-IDpeningkatan-kemampuan-belajar-hitung-pad.pdf

Armstrong, T. (2004). Kamu Lebih Cerdas daripada yang Kamu Duga. Batam: Interaksara.

Bautty, S.N. (2016). Telaah Sistem Pendidikan di Finlandia dan Relevansinya dengan Sistem Pendidikan Islam di Indonesia (Kajian Terhadap Buku Finnish Lessons: Mengajar Lebih Sedikit, Belajar Lebih Banyak Ala Finlandia Karya Pasi Sahlberg), Yogyakarta: Universitas Islam Negeri Yogjakarta.

Charlesworth, K. \& Lind. (2010). Math and Science for Young Children. United States of America: WARDWORTH Cendage Learning. 
Chatib, M. (2012). Orang tuanya Manusia: Melejitkan Potensi dan Kecerdasan dengan Menghargai Fitrah Setiap Anak. Bandung: Kaifa.

Damayanti, A. D. M. \& Putranti, R. D. (2016). Pembelajaran Matematika dalam Permainan Tradisional Engklek Untuk Siswa SD Kelas V. Prosiding Seminar Nasional Matematika dan Terapannya Universitas Jenderal Soedirman: 253260.

Fitria, A. (2013). Mengenalkan dan Membelajarkan Matematika Pada Anak Usia Dini. Mu'adalah. Jurnal Studi Gender dan Anak, 1(2), 1-11.

Gardner, Howard. (1993). Frame of Mind. New York: Basic Books.

Gugus Tugas Percepatan Penanganan COVID-19. (2020). Infografis COVID-19 (3 September 2020). (online). Diakses pada 4 September 2020. https://covid19.go.id/p/berita/infografis-covid-19-3-september-2020

Kemdikbud, D. P. (2020). Bermain Matematika yang Menyenangkan dengan Anak di Rumah. Kementerian Pendidikan dan Kebudayaan Republik Indonesia. 1-26.

Kemendikbud. (2020). Penyesuaian Kebijakan Pembelajaran di Masa Pandemi COVID-19. (online) Diakses pada 12 Agustus 2020. https://www.kemdikbud.go.id/main/files/download/c4c7ec76db850c3

Lestariningrum, A. (2015). Pemanfaatan media biji-bijian sebagai sumber belajar bidang pengembangan matematika pada anak usia dini. Efektor, 2(2), 1-7.

Maritaria, T. dan Mariana, N. (2019). Eksplorasi Konsep Matematika Sekolah Dasar Dalam Tari Kreasi. JPGSD, 7(3), 3029 - 3039.

Nugraha, M., R. (2017). Meningkatkan Keterampilan Proses Sains Anak Usia Dinimelalui Aktivitas Berkebun. Early Childhood: Jurnal Pendidikan, 1(1).

Mirawati, M., Anggarasari, N. H., \& Nurkamilah, M. (2018). Fun Cooking: Pembelajaran Matematika yang Menyenangkan Bagi Anak Usia Dini. Early Childhood: Jurnal Pendidikan, 2(1), 1-6.

Nasution, M. K. (2017). Penelaahan literatur. Teknik Penulisan Karya Ilmiah, 3. Sumatera utara. Researchgate. (online) Diakses pada 12 Agustus 2020.

Praheto, B., E. (2018). Pembelajaran Bahasa Indonesia dan Daerah Berbasis Permainan Tradisional Di Sekolah Dasar. Konferensi Nasional Bahasa dan Sastra III.

Purwantyo, A., Tomoliyus. (2018). Pengembangan Model Pembelajaran Integratif Penjasorkes Sekolah Dasar. Jurnal Pendidikan Jasmani Indonesia, 14(2), 3849.

Rahayu, R. (2016). Permainan Edukasi Berbasis Keunggulan Lokal dalam Pembelajaran Matematika. Prosiding Seminar Nasional Psikologi Universitas Muria Kudus.

Respitawulan, Nurul Afrianti, Y., \& Permanasari, U. (2014). Konstruksi Origami Sebagai Strategi Pembelajaran Matematika Untuk Anak Usia Dini. Prosiding SnaPP 2017 Sosial, Ekonomi, dan Humaniora,120-126

Tam, G., \& El-Azar, D. (2020). 3 Ways the Coronavirus Pandemic could Reshape Education. Retrieved May 13, 2020. (online) Diakses pada 12 Agustus 2020.https://www.weforum.org/agenda/2020/03/3-wayscoronavirus-is reshaping-education-and-what-changes-might-be-here-to-stay/

Tim KPAI. (2020). Ada 246 Aduan di KPAI soal Belajar Daring, Siswa Keluhkan Tugas Menumpuk-Kuota. Online. Diakses pada tanggal 11 Agustus 2020. https://www.kpai.go.id/berita/ada-246-aduan-di-kpai-soal-belajar-daringsiswa-keluhkan-tugas-menumpuk-kuota

UNDP. (2020). Human Development Perspectives Covid-19 And Human Development: Assessing the Crisis, Envisioning the Recovery Available. USA: AGS

UNESCO. (2020). Education: From Disruption to Recovery. Available online: https://en.unesco.org/covid19/educationresponse (accessed on 6 August 2020).

Zhang, T. (2020). Learning from the emergency remote teaching learning in China when primary and secondary schools were disrupted by COVID-19 pandemic. Journal of Risk and Financial Management, 13(55). 